This document was prepared in conjunction with work accomplished under Contract No. DE-AC09-96SR18500 with the U.S. Department of Energy.

This work was prepared under an agreement with and funded by the U.S. Government. Neither the U. S. Government or its employees, nor any of its contractors, subcontractors or their employees, makes any express or implied: 1 . warranty or assumes any legal liability for the accuracy, completeness, or for the use or results of such use of any information, product, or process disclosed; or 2 . representation that such use or results of such use would not infringe privately owned rights; or 3 . endorsement or recommendation of any specifically identified commercial product, process, or service. Any views and opinions of authors expressed in this work do not necessarily state or reflect those of the United States Government, or its contractors, or subcontractors. 
WSRC-STI-2007-00200

To be published in the Proceedings of PVP2007

2007 ASME Pressure Vessels and Piping Division Conference

July 22-26, 2007, San Antonio, Texas

PVP2007-26660

\section{DEVELOPMENT AND APPLICATION OF MATERIALS PROPERTIES FOR FLAW STABILITY ANALYSIS IN EXTREME ENVIRONMENT SERVICE}

\author{
Robert L. Sindelar \\ Savannah River National Laboratory \\ Aiken, SC 29808, USA
}

Bruce J. Wiersma

Savannah River National Laboratory

Aiken, SC 29808, USA

\author{
Poh-Sang Lam \\ Savannah River National Laboratory \\ Aiken, SC 29808
}

Karthik H. Subramanian

Savannah River National Laboratory

Aiken, SC 29808, USA

\author{
Andrew J. Duncan \\ Savannah River National Laboratory \\ Aiken, SC 29808
}

\author{
James B. Elder \\ Savannah River National Laboratory \\ Aiken, SC 29808, USA
}

\begin{abstract}
Discovery of aging phenomena in the materials of a structure may arise after its design and construction that impact its structural integrity. This condition can be addressed through a demonstration of integrity with the material-specific degraded conditions. Two case studies of development of fracture and crack growth property data, and their application in development of in-service inspection programs for nuclear structures in the defense complex are presented. The first case study covers the development of fracture toughness properties in the form of J-R curves for rolled plate Type 304 stainless steel with Type 308 stainless steel filler in the application to demonstrate the integrity of the reactor tanks of the heavy water production reactors at the Savannah River Site. The fracture properties for the base, weld, and heat-affected zone of the weldments irradiated at low temperatures $\left(110^{\circ}-150^{\circ} \mathrm{C}\right)$ up to $6.4 \mathrm{dpa}_{\mathrm{NRT}}$ and $275 \mathrm{appm}$ helium were developed. An expert group provided consensus for application of the irradiated properties for material input to acceptance criteria for ultrasonic examination of the reactor tanks. Dr. Spencer H. Bush played a lead advisory role in this work. The second case study covers the development of fracture toughness for A285 carbon steel in high level radioactive waste tanks. The approach in this case study incorporated a statistical experimental design for material testing to address metallurgical factors important to fracture toughness. Tolerance intervals were constructed to identify the lower bound fracture toughness for material input to flaw disposition through acceptance by analysis.
\end{abstract}

Keywords: radiation effects, fracture toughness, aging, IGSCC, safety factors.

\section{INTRODUCTION}

Aging of structures in aggressive service environments may result in degradation of the material properties, or the loss of net section, or both. Continued safe operation of the structure requires that the degradation be evaluated and shown to be acceptable. This is especially important if the replacement of the structure is cost or physically prohibitive. A critical aspect to assess flaw tolerance in an aging structure in a service environment is the application of material properties that accurately match those of the structure in service.

Spencer Bush's early career work involved characterization of the effects of radiation on structural and cladding materials in light water reactor systems. Dr. Bush was prominent later in his career in the codification of methods to disposition serviceinduced flaws through his work and service as chairman of the ASME Subcommittee on Nuclear Inservice Inspection. This paper brings together these topics in two case studies of development and application of material properties to structures in nuclear service at the Savannah River Site.

The first case study involved flaw acceptance in the sidewall of the reactor tanks of the production reactors at the Savannah River Site. ${ }^{1}$ The SRS tanks are cylinders approximately 16 feet in diameter and 14 feet high that were not pressurized except for a 5 psig helium blanket gas in addition to the hydrostatic head of heavy water $\left(D_{2} \mathrm{O}\right)$ moderator. The tanks were constructed of American Iron and Steel Institute Type 304 stainless steel plates, 0.5 inches thick, fabricated into cylindrical shell with four to six wrought plates per tank. All joining was performed with multipass Metal Inert Gas welding (Type 308 stainless steel filler wire under helium cover gas). The primary coolant piping of the reactors, fabricated from similar materials, had an incidence of Intergranular Stress Corrosion Cracking (IGSCC) in the primary coolant piping in their service, and cracking had been observed to a limited extent in one of the tanks.

The reactor tanks did not have irradiation surveillance

\footnotetext{
1 The SRS production reactors have been permanently shut down since 1993.
} 
coupons to track the effects of neutron irradiation during operation. The approach was to develop properties of archival Type 304 stainless steel with Type 308 filler from archival piping of the 1950s era by irradiating mechanical specimens cut from SRS reactor piping. $^{2}$ Properties for application to structural and flaw stability analysis were selected from this data set. Acceptance criteria for in-service inspection using ultrasonic test examination were developed to disposition indications.

The second case study involves flaw acceptance in the sidewalls of the high level waste storage tanks at the Savannah River Site. The tanks are approximately 80 feet in diameter and 30 feet high. The Type I and II design tanks at the site used ASTM A285 Grade B carbon steel as the primary material of construction and were joined using GMAW with E6010 weld material. The tanks are subject to nitrate-induced stress corrosion cracking and several of the tanks have developed cracks.

The specific heats and compositions of the several of the plates used to fabricate the tanks were not available. The approach to develop property input to flaw stability analysis was to identify factors in chemistry and microstructure of the A285 plates important to mechanical response. A statistical experimental design for material testing was constructed to address metallurgical factors important to fracture toughness. Lower bound properties were identified for acceptance by analysis.

\section{REACTOR TANK MATERIAL PROPERTIES}

Neutron irradiation of austenitic stainless steels at low temperatures $\left(<300{ }^{\circ} \mathrm{C}\right)$ causes marked hardening (increased yield strength up to several times the initial strength with reduced work hardenability, the difference between the yield and tensile strengths) and reduces fracture toughness. A dataset of properties from mechanical specimens (Compact Tension, Tensile, and Charpy V-notch) of Types 304 and 304L stainless steel piping and plate materials and Type 308 stainless steel weld materials was developed through several irradiation campaigns and reported in the literature [1]. The dataset was developed from archival reactor primary coolant piping materials tested in the non-irradiated condition and following irradiation. Weldment components included base, weld, and weld heat-affected-zone (HAZ) components in both the C-L and L-C orientations. Additional specimens of identical design were irradiated in the High Flux Isotope Reactor (HFIR) and tested subsequent to those reported in reference 1 , and are summarized in this paper. Table 1 shows the irradiation and test conditions of the materials.

Mechanical testing of specimens from the $12 \mathrm{M}$ capsule, a capsule irradiated in the HFIR, provide information on the effect of high thermal neutron fluence producing helium contents at and above the tank sidewall maximum level of 140

\footnotetext{
${ }^{2}$ A maximum exposure of $1.86 \times 10^{21} \mathrm{n} / \mathrm{cm}^{2}\left(\mathrm{E}_{\mathrm{n}}>0.1 \mathrm{MeV}\right)$ with a maximum $0^{22} \mathrm{n} / \mathrm{cm}^{2}$ at irradiation temperatures from thermal neutron fluence of $1.16 \times 10 \mathrm{n} / \mathrm{cm}$ at irradiation temperatures from
approximately 25 to $125^{\circ} \mathrm{C}$ had occurred in the SRS tank sidewalls. This exposure produced 1.4 displacements per atom (dpa) with a maximum helium content of 140 atomic parts per million (appm).
}

atomic parts per million (appm). Several of the 12M tensile, Charpy V-notch, and compact tension specimens contained neutronically-generated helium at levels bounding the reactor tank wall maximum level.

The helium content of the specimens was estimated as follows. Irradiation of austenitic stainless steels produces helium primarily through fast neutron $(n, \alpha)$ reactions with the major alloying components, through a two-step thermal neutron reaction with $\mathrm{Ni}^{58}$, and with fast and thermal neutron reactions with $\mathrm{B}^{10}$, depending on the reactor spectrum. The fast neutron cross section for the production helium for nickel, chromium, and iron are on the order of $1 \mathrm{mb}$ for neutron energies on the order of $1 \mathrm{MeV}$ [2].

The HFIR is a mixed-spectrum reactor with the thermal flux in the removable beryllium positions calculated to be 1.351 of the fast $\left(\mathrm{E}_{\mathrm{n}}>0.1 \mathrm{MeV}\right)$ flux. The primary source of helium in the HFIR specimens is from the two-step neutron reaction with $\mathrm{Ni}^{58}$. Following the method given in reference 3, the calculation of helium via the two-step neutron reaction with $\mathrm{Ni}^{58}$ is shown below.

Calculation of Helium Build-in from Two-Step Thermal Neutron Reaction with Ni-58:

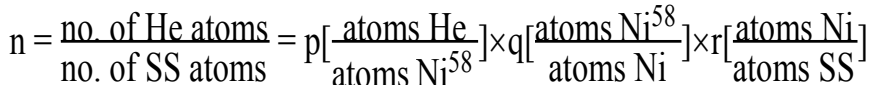

With

$$
\mathrm{p}=\frac{\sigma_{\alpha}}{\sigma_{\mathrm{T}}} \times \frac{\sigma_{\mathrm{T}} \times\left(1-\mathrm{e}^{-\sigma_{\gamma} \times \Phi}\right)-\sigma_{\gamma} \times\left(1-\mathrm{e}^{-\sigma_{\mathrm{T}} \times \Phi}\right)}{\sigma_{\mathrm{T}}-\sigma_{\gamma}}
$$

where $\sigma_{\gamma}$ and $\sigma_{\mathrm{T}}$ are the capture and total absorption thermal neutron cross sections, respectively, for $\mathrm{Ni}^{58} ; \sigma_{\alpha}$ is the alpha emittance thermal neutron cross section for $\mathrm{Ni}^{59}$; and $\Phi$ is the thermal fluence. The values for these cross sections are from reference 4 as shown below.

\section{Thermal Neutron Reaction Cross Sections [4]:}

$\mathrm{B}^{10}(\mathrm{n}, \alpha) \mathrm{Li}^{7}: \sigma_{\alpha}(2200 \mathrm{~m} / \mathrm{s})=3837 \pm 9$ barns $(1$ barn $=$ $\left.10^{-24} \mathrm{~cm}^{2}\right)$

$\mathrm{Ni}^{58}(\mathrm{n}, \gamma) \mathrm{Ni}^{59}: \sigma_{\gamma}($ thermal spectrum-averaged $)=4.6 \pm 0.3$ barns

$\mathrm{Ni}^{59}(\mathrm{n}, \alpha) \mathrm{Fe}^{56}: \sigma_{\alpha}$ (thermal spectrum-averaged $)=12.3 \pm$ 0.6 barns

$\mathrm{Ni}^{59}(\mathrm{n}, \mathrm{T})$ (Total absorption): $\sigma_{\mathrm{T}}$ (thermal spectrumaveraged) $=92 \pm 4$ barns

Also, $\mathrm{q}=0.683$, the natural isotope abundance of $\mathrm{Ni}^{58}$ in nickel, and 


$$
\mathrm{r}=\frac{\mathrm{wt} . \% \text { nickel }}{100 \text { wt. } \% \mathrm{SS}} \times \frac{8.32 \frac{\mathrm{gm} \text { of SS }}{\mathrm{cm}^{3}}}{58.71 \frac{\mathrm{gm} \mathrm{of} \mathrm{nickel}}{\text { mole of nickel }}} \times \frac{6.023 \times 10^{23} \frac{\text { atoms of nickel }}{\text { mole of nickel }}}{9.1 \times 10^{22} \frac{\text { atoms of SS }}{\mathrm{cm}^{3}}}
$$

Helium assay chips from selected specimens were measured by fusion analysis by Dr. B. M. Oliver and Dr. H. Farrar IV. The results are shown in Table 2. The actual boron content of the piping materials reported to contain contents of 10 to $20 \mathrm{wppm}$, near the reported resolution of $\pm 10 \mathrm{wppm}$, is most likely negligible. The helium content of approximately 0.07 appm in the base (and HAZ) of the University of Buffalo Reactor irradiated specimens is close to that expected for the fast neutron reactions and is well below that expected from the boron assay of 10 to $20 \mathrm{wppm}$. The helium content at approximately 1 appm in the specimen $4 \mathrm{~W}$ weld deposit is consistent with the thermal reaction with $\mathrm{B}^{10}$ and thus the boron assays at the $50 \mathrm{wppm}$ are expected to be more accurate. Similarly, the helium contents of the 4M specimens listed in Table 2 are close to the predicted content (Table 1) and therefore the actual boron contents are negligible in the base materials. The predicted helium content of the 1Q specimens (Table 1) are, however, less than the measured values listed in Table 2. The actual boron content of the F50 plate material is therefore non-negligible and is close to the reported $10 \mathrm{wppm}$ level. The close agreement of the measured helium content of the $4 \mathrm{M}$ specimens with the predicted contents shows that the generation of helium from the two-step thermal neutron reaction with $\mathrm{Ni}^{58}$ is the primary source of helium. Therefore, the predicted values for the helium content of the $12 \mathrm{M}$ specimen materials should be accurate.

The recoil of $\mathrm{He}^{4}$ and $\mathrm{Fe}^{56}$ also produces displacement damage [5]. Greenwood [5] has calculated a value of 1/567 dpa for each appm of helium produced from the two-step thermal reaction with $\mathrm{Ni}^{58}$. This contribution to displacement damage has not been added to the dpaNRT values calculated per ASTM E693 shown in Table 1. The exposure parameter dpanRT is the dpa model by Norget, Robinson, and Torrens [6].

\section{Mechanical Properties of Low Temperature Irradiated Stainless Steel}

The dataset of irradiated materials included reactor tank sidewall materials from the Savannah River Site R Reactor, specimens of 1950s vintage stainless steel from a reactor thermal shield mock-up irradiated in the core of P Reactor, a 1960s-vintage plate of Type 304L stainless steel irradiated in the High Flux Isotope Reactor (HFIR), and archival 1950svintage piping materials (Type 304 stainless steel with Type 308 stainless steel weld materials) irradiated in the University of Buffalo Reactor and the HFIR as part of the irradiation and testing program [1]. The fast neutron fluence and displacement damage of these specimens provided a range of exposures up to and exceeding the lifetime fast fluence and displacement damage of the SRS production reactor tank sidewalls.

The mechanical properties' results of the $12 \mathrm{M}$ testing are summarized in table 3. A comparison of the $12 \mathrm{M}$ results with the previous results in the dataset [1] show that the helium build-in does not cause an additional loss of fracture toughness at the test conditions pertinent to the service conditions of the reactor tanks.

The archival piping materials included base, weld, and weld heat-affected-zone (HAZ) weldment components in both the C-L and L-C orientations. The $12 \mathrm{M}$ results were consistent with the previous testing of materials in the non-irradiated and irradiated conditions that show the C-L specimen orientation to be significantly less tough that the L-C orientation for the base and HAZ weldment components.

The HAZ component materials in the database show an increased sensitivity to irradiation (greater loss of toughness) compared to base component materials. The range of values of residual toughness (defined as the value of the $\mathrm{J}_{\text {deformation }}-\mathrm{R}$ curve@1 mm crack extension in the irradiated condition divided by the non-irradiated value for the corresponding material heat and specimen orientation) of the HAZ component is 41 to $54 \%$, whereas the range of residual toughness values of the base component is 65 to $89 \%$ for the $0.4 \mathrm{~T}$ planform specimens for the $25^{\circ} \mathrm{C}$ and $125^{\circ} \mathrm{C}$ test temperatures. Figure 1 shows the residual toughness from the $125^{\circ} \mathrm{C}$ tests.

The HAZ microstructure from the archival piping material source contained chromium carbide $\left(\mathrm{M}_{23} \mathrm{C}_{6}\right)$ precipitation at the grain boundaries as a result of the joining. This condition renders it "sensitized," susceptible to Intergranular Stress Corrosion Cracking under tensile stress in an environment promoting corrosion [7]. The barrier hardening in the matrix caused during the irradiation likely causes additional strain at the grain boundaries during deformation that is less likely to be accommodated in the sensitized microstructure.

The elastic-plastic fracture toughness results show only little or no continued decrease with exposure over the entire range of dpanRT (0.21 to 6.4) in this study (Figure 1).

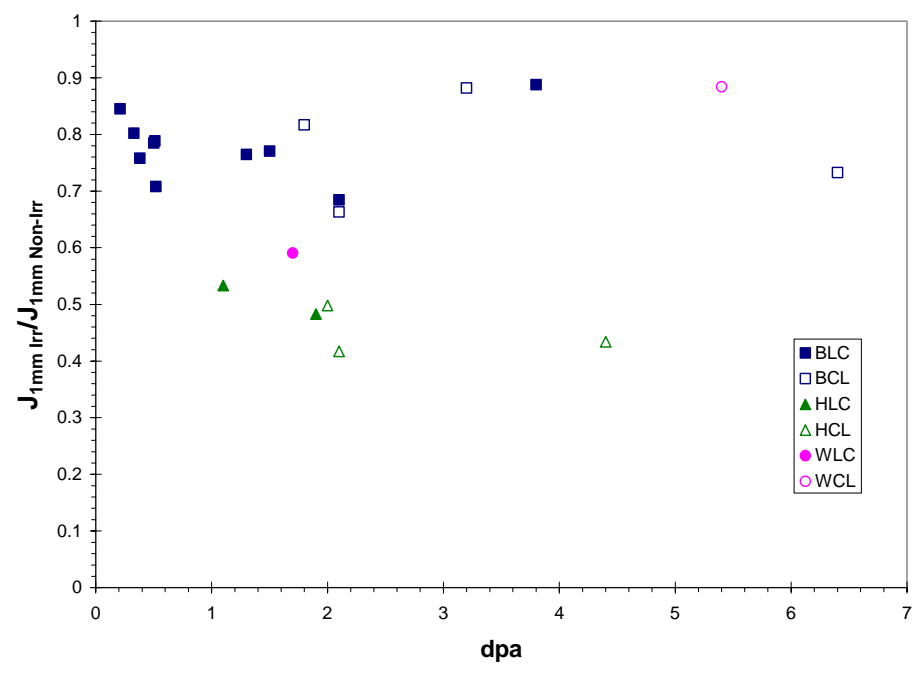

Figure 1 - Normalized Fracture Toughness of Type 304 Stainless Steel Base (BLC and BCL) and Heat-Affected-Zone (HLC and HCL), and Type 308 Stainless Steel Weld (WLC and WCL) Materials, Following Low-Temperature ( $\mathrm{T}_{\text {irradiation }}$ $110^{\circ}-150^{\circ} \mathrm{C}$ ) Neutron Irradiation. The specimens were tested at $125^{\circ} \mathrm{C}$ 
Table 1 - Irradiation Exposure Parameters for Mechanical Test Specimens. The displacements per atom (dpa) values were calculated in accordance with ASTM E693. The contribution to dpa of 1/567 per 1 appm helium has not been added to the dpa results. [Note the thermal fluences of the 1Q and 4M capsule specimens, previously reported incorrectly in reference 1, have been corrected in this table].

\begin{tabular}{|c|c|c|c|c|c|c|}
\hline $\begin{array}{c}\text { Specimen ID } \\
\text { HFIR Capsule }\end{array}$ & $\begin{array}{c}\text { Specimen Type, Test } \\
\text { Temp. }\end{array}$ & Orientation & $\begin{array}{c}\text { Thermal Fluence, } \\
10^{21} \mathrm{n} / \mathrm{cm}^{2}\end{array}$ & $\begin{array}{c}\text { Fast Fluence, En }> \\
0.1 \mathrm{MeV}, 10^{21} \mathrm{n} / \mathrm{cm}^{2}\end{array}$ & $\begin{array}{c}\text { dpa }_{\text {NRT }} \text { (ASTM } \\
\text { E693) }\end{array}$ & $\begin{array}{c}\text { Helium (estimated), } \\
\text { appm }\end{array}$ \\
\hline \multicolumn{7}{|l|}{ 1Q Capsule } \\
\hline F50-12 & $\mathrm{T}, 125^{\circ} \mathrm{C}$ & L-T & 0.49 & 0.36 & 0.21 & 0.5 \\
\hline F50-9 & $\mathrm{T}, 125^{\circ} \mathrm{C}$ & L-T & 0.81 & 0.60 & 0.34 & 1.2 \\
\hline F50-1 & $\mathrm{T}, 125^{\circ} \mathrm{C}$ & L-T & 1.04 & 0.77 & 0.43 & 2.0 \\
\hline F50-6 & $\mathrm{T}, 125^{\circ} \mathrm{C}$ & L-T & 1.20 & 0.89 & 0.50 & 2.7 \\
\hline F50-8 & $\mathrm{T}, 125^{\circ} \mathrm{C}$ & L-T & 1.24 & 0.92 & 0.52 & 2.8 \\
\hline F50-13 & $\mathrm{CVN}, 125^{\circ} \mathrm{C}$ & L-T & 0.49 & 0.36 & 0.21 & 0.5 \\
\hline F50-19 & $\mathrm{CVN}, 125^{\circ} \mathrm{C}$ & L-T & 0.81 & 0.60 & 0.34 & 1.2 \\
\hline F50-14 & $\mathrm{CVN}, 125^{\circ} \mathrm{C}$ & L-T & 1.04 & 0.77 & 0.43 & 2.0 \\
\hline F50-23 & $\mathrm{CVN}, 125^{\circ} \mathrm{C}$ & L-T & 1.2 & 0.89 & 0.50 & 2.7 \\
\hline F50-17 & $\mathrm{CT}, 125^{\circ} \mathrm{C}$ & L-T & 0.49 & 0.36 & 0.21 & 0.5 \\
\hline F50-18 & $\mathrm{CT}, 125^{\circ} \mathrm{C}$ & L-T & 0.78 & 0.58 & 0.33 & 1.1 \\
\hline F50-12 & $\mathrm{CT}, 125^{\circ} \mathrm{C}$ & L-T & 0.91 & 0.67 & 0.38 & 1.5 \\
\hline F50-19 & $\mathrm{CT}, 125^{\circ} \mathrm{C}$ & L-T & 1.19 & 0.88 & 0.50 & 2.6 \\
\hline F50-13 & $\mathrm{CT}, 125^{\circ} \mathrm{C}$ & L-T & 1.22 & 0.90 & 0.51 & 2.8 \\
\hline F50-8 & $\mathrm{CT}, 125^{\circ} \mathrm{C}$ & L-T & 1.24 & 0.92 & 0.52 & 2.8 \\
\hline \multicolumn{7}{|l|}{ 4M Capsule } \\
\hline 3HA8 & $\mathrm{T}, 125^{\circ} \mathrm{C}$ & L-C & 2.43 & 1.8 & 1.0 & 9.3 \\
\hline 1BB1 & $\mathrm{T}, 125^{\circ} \mathrm{C}$ & L-C & 3.65 & 2.7 & 1.5 & 20 \\
\hline 5BA5 & $\mathrm{T}, 125^{\circ} \mathrm{C}$ & C-L & 4.46 & 3.3 & 1.9 & 30 \\
\hline 4BB2 & $\mathrm{T}, 125^{\circ} \mathrm{C}$ & C-L & 5.00 & 3.7 & 2.1 & 37 \\
\hline 1BB4 & $\mathrm{T}, 125^{\circ} \mathrm{C}$ & L-C & 5.13 & 3.8 & 2.1 & 37 \\
\hline $6 \mathrm{~W} 1$ & $\mathrm{CVN}, 125^{\circ} \mathrm{C}$ & L-C & 2.43 & 1.8 & 1.0 & 10 \\
\hline 6HA6 & $\mathrm{CVN}, 125^{\circ} \mathrm{C}$ & L-C & 3.65 & 2.7 & 1.5 & 21 \\
\hline $3 \mathrm{HB} 1$ & $\mathrm{CVN}, 125^{\circ} \mathrm{C}$ & L-C & 4.46 & 3.3 & 1.9 & 29 \\
\hline 4BB9 & $\mathrm{CVN}, 125^{\circ} \mathrm{C}$ & C-L & 5.00 & 3.7 & 2.1 & 37 \\
\hline 1BB5 & $\mathrm{CVN}, 125^{\circ} \mathrm{C}$ & L-C & 5.13 & 3.8 & 2.1 & 37 \\
\hline 3HA5 & $\mathrm{CT}, 125^{\circ} \mathrm{C}$ & L-C & 2.43 & 1.8 & 1.1 & 9.3 \\
\hline $1 \mathrm{BB} 8$ & $\mathrm{CT}, 125^{\circ} \mathrm{C}$ & $\mathrm{L}-\mathrm{C}$ & 2.97 & 2.2 & 1.3 & 13 \\
\hline 1BB16 & $\mathrm{CT}, 125^{\circ} \mathrm{C}$ & L-C & 3.51 & 2.6 & 1.5 & 18 \\
\hline $2 \mathrm{~W} 2$ & $\mathrm{CT}, 125^{\circ} \mathrm{C}$ & L-C & 3.92 & 2.9 & 1.7 & 26 \\
\hline 5BA7 & $\mathrm{CT}, 125^{\circ} \mathrm{C}$ & C-L & 4.32 & 3.2 & 1.8 & 28 \\
\hline $3 \mathrm{HB} 4$ & $\mathrm{CT}, 125^{\circ} \mathrm{C}$ & L-C & 4.59 & 3.4 & 1.9 & 30 \\
\hline 7HA5 & $\mathrm{CT}, 125^{\circ} \mathrm{C}$ & C-L & 4.86 & 3.6 & 2.1 & 34 \\
\hline 7HA7 & $\mathrm{CT}, 125^{\circ} \mathrm{C}$ & C-L & 4.86 & 3.6 & 2.0 & 34 \\
\hline 1BB9 & $\mathrm{CT}, 125^{\circ} \mathrm{C}$ & L-C & 5.00 & 3.7 & 2.1 & 36 \\
\hline 4BB10 & $\mathrm{CT}, 125^{\circ} \mathrm{C}$ & C-L & 5.13 & 3.8 & 2.1 & 39 \\
\hline \multicolumn{7}{|l|}{ 12M Capsule } \\
\hline $4 \mathrm{BB} 1$ & $\mathrm{~T}, 25^{\circ} \mathrm{C}$ & C-L & 7.3 & 5.4 & 3.1 & 74 \\
\hline $5 \mathrm{~W} 1$ & $\mathrm{~T}, 25^{\circ} \mathrm{C}$ & L-C & 10.8 & 8.0 & 4.6 & 155 \\
\hline $5 \mathrm{~W} 4$ & $\mathrm{~T}, 125^{\circ} \mathrm{C}$ & L-C & 13.2 & 9.8 & 5.6 & 217 \\
\hline 4BB5 & $\mathrm{T}, 125^{\circ} \mathrm{C}$ & C-L & 15.2 & 11.3 & 6.4 & 259 \\
\hline 1BB2 & $\mathrm{T}, 125^{\circ} \mathrm{C}$ & L-C & 14.6 & 10.8 & 6.1 & 232 \\
\hline $4 \mathrm{BB} 8$ & $\mathrm{CVN}, 125^{\circ} \mathrm{C}$ & $\mathrm{C}-\mathrm{L}$ & 7.3 & 5.4 & 3.1 & 74 \\
\hline $6 \mathrm{~W} 5$ & $\mathrm{CVN}, 25^{\circ} \mathrm{C}$ & L-C & 10.8 & 8.0 & 4.6 & 155 \\
\hline $6 \mathrm{~W} 2$ & $\mathrm{CVN}, 125^{\circ} \mathrm{C}$ & L-C & 15.3 & 11.3 & 6.4 & 276 \\
\hline 1HA6 & $\mathrm{CVN}, 125^{\circ} \mathrm{C}$ & L-C & 13.2 & 9.8 & 5.6 & 200 \\
\hline 4BB11 & $\mathrm{CT}, 125^{\circ} \mathrm{C}$ & C-L & 7.2 & 5.4 & 3.2 & 74 \\
\hline 1BB11 & $\mathrm{CT}, 125^{\circ} \mathrm{C}$ & $\mathrm{L}-\mathrm{C}$ & 9.0 & 6.7 & 3.8 & 103 \\
\hline 7HA6 & $\mathrm{CT}, 125^{\circ} \mathrm{C}$ & C-L & 10.5 & 7.8 & 4.4 & 136 \\
\hline $7 \mathrm{~W} 4$ & $\mathrm{CT}, 125^{\circ} \mathrm{C}$ & C-L & 12.8 & 9.5 & 5.4 & 201 \\
\hline 1BB18 & $\mathrm{CT}, 25^{\circ} \mathrm{C}$ & C-L & 13.7 & 10.2 & 5.8 & 209 \\
\hline 4BB12 & $\mathrm{CT}, 125^{\circ} \mathrm{C}$ & C-L & 15.2 & 11.3 & 6.4 & 259 \\
\hline $7 \mathrm{~W} 3$ & $\mathrm{CT}, 25^{\circ} \mathrm{C}$ & C-L & 12.2 & 9.0 & 5.1 & 186 \\
\hline 7HA8 & $\mathrm{CT}, 25^{\circ} \mathrm{C}$ & C-L & 9.6 & 7.1 & 4.1 & 117 \\
\hline
\end{tabular}


Table 2 - Measured helium concentrations from selected UBR- and HFIR-irradiated 1Q and 4M specimens.

\begin{tabular}{|c|c|c|}
\hline $\begin{array}{c}\text { Irradiation: Specimen } \\
\text { Identification }\end{array}$ & Boron (wppm) & $\begin{array}{c}\text { Helium (atomic parts per } \\
\text { million) }\end{array}$ \\
\hline \hline UBR: 3HA34 & $10 \pm 10$ & $0.0673 \pm 0.0088$ \\
\hline UBR: 3BA20 & $10 \pm 10$ & $0.0769 \pm 0.0007$ \\
\hline UBR: 1HB16 & $20 \pm 10$ & $0.0684 \pm 0.0002$ \\
\hline UBR: 4W14 & $50 \pm 10$ & 1.404 \\
\hline UBR: 4W15 & $50 \pm 10$ & 0.996 \\
\hline UBR: 4HA19 & $20 \pm 10$ & $0.0703 \pm 0.0001$ \\
\hline 3BA20 & $10 \pm 10$ & 0.09759 \\
\hline 1HB16 & $20 \pm 10$ & 0.06579 \\
\hline F50-13 & $10 \pm 10$ & 3.27 \\
\hline F50-19 & $10 \pm 10$ & 3.75 \\
\hline F50-14 & $10 \pm 10$ & 5.24 \\
\hline F50-23 & $10 \pm 10$ & 7.61 \\
\hline F50-X1 & $10 \pm 10$ & $8.12 *$ \\
\hline 6W1 & $<10$ & 12.55 \\
\hline 6HA6 & $10 \pm 10$ & 28.7 \\
\hline 3HB1 & $20 \pm 10$ & 39.5 \\
\hline 4BB9 & $20 \pm 10$ & 35.5 \\
\hline 1BB5 & $20 \pm 10$ & \\
\hline shown in this table. It is assumed that the results were inadvertently switched. \\
\hline
\end{tabular}

Table 3 - Summary of Results of the HFIR 12M Capsule Mechanical Specimen Testing

\begin{tabular}{|l|l|l|l|l|l|l|l|}
\hline Specimen & Orientation & Type & Test Temp. $\left({ }^{\circ} \mathbf{C}\right)$ & $\begin{array}{l}\text { Engr. Yield } \\
\mathbf{( 0 . 2 \% , ~ M P a ) ~}\end{array}$ & $\begin{array}{l}\text { Engr. Tensile } \\
(\mathbf{M P a})\end{array}$ & $\begin{array}{l}\text { Uniform Elong. Total Elong. } \\
(\mathbf{\%} \text { in 20.3 mm) }\end{array}$ & $\begin{array}{l}\text { (\% in 20.3 mm) } \\
\text { 4BB1 }\end{array}$ \\
\hline C-L & T & 23 & 704 & 767 & 31.13 & 31.85 \\
\hline 5W1 & L-C & T & 23 & 732 & 774 & 19.42 & 31.85 \\
\hline 5W4 & L-C & T & 125 & 621 & 645 & 9.77 & 19.01 \\
\hline 4BB5 & C-L & T & 125 & 664 & 683 & 22.57 & 33.78 \\
\hline 1BB2 & L-C & T & 125 & 655 & 663 & 20.92 & 32.21 \\
\hline
\end{tabular}

\begin{tabular}{|l|l|l|l|l|}
\hline Specimen & Orientation & Type & Test Temp. $\left({ }^{\circ} \mathbf{C}\right)$ & Absorbed Energy $(\mathbf{J})$ \\
\hline 4BB8 & C-L & CVN & 125 & 90.6 \\
\hline 6W5 & L-C & CVN & 22 & 94.4 \\
\hline 6W2 & L-C & CVN & 125 & 103 \\
\hline 1HA6 & L-C & CVN & 125 & 110 \\
\hline
\end{tabular}

\begin{tabular}{|c|c|c|c|c|c|c|}
\hline Specimen & Orientation & Type & Test Temp $\left({ }^{\circ} \mathrm{C}\right)$ & $\mathrm{J}_{\mathrm{IC}}$ (deformation) & $\begin{array}{l}\text { Power Law, C } \\
\mathbf{J}=C \Delta \mathbf{a}^{\mathrm{N}},\left(\mathrm{kJ} / \mathrm{m}^{2}\right)\end{array}$ & Power Law, N \\
\hline 4BB11 & C-L & CT & 125 & 196.64 & 326.13 & 0.55788 \\
\hline 1BB11 & L-C & $\mathrm{CT}$ & 125 & 436.63 & 534.86 & 0.46507 \\
\hline 7HA6 & C-L & CT & 125 & 89.15 & 103.17 & 0.12113 \\
\hline $7 \mathrm{~W} 4$ & C-L & CT & 125 & 371.49 & 470.41 & 0.53201 \\
\hline 1BB18 & C-L & CT & 25 & 187.09 & 315.27 & 0.50354 \\
\hline 4BB12 & C-L & CT & 125 & 194.35 & 268.63 & 0.35461 \\
\hline $7 \mathrm{~W} 3$ & C-L & CT & 25 & 217.3 & 341.93 & 0.45201 \\
\hline $7 \mathrm{HA} 8$ & C-L & CT & 25 & 55.31 & 120.21 & 0.54691 \\
\hline
\end{tabular}

\section{Microstructure of Irradiated Materials}

The mechanical response to irradiation was also investigated by characterizing the defect microstructure and applying models from the literature describing the change in mechanical properties with exposure. This supports the understanding of the degradation mechanisms, and confidence in the application of mechanical property results. 
Small lattice defect complexes are the predominant microstructure features produced during irradiation of the materials causing the change in mechanical properties $[1,8]$. The microstructures of selected R-tank, UBR, and 1Q specimens were characterized by Transmission Electron Microscopy by measuring the size and number density of the lattice defect complexes produced during irradiation. A summary of the defect cluster size and number density is contained in the table 4. Helium bubbles with a mean diameter of $2.5 \mathrm{~nm}$ and a number density of approximately $1.5 \mathrm{x}$ $10^{16} / \mathrm{cm}^{3}$ were observed in the R-tank specimen, but were not clearly resolvable $(>2 \mathrm{~nm})$ in the UBR and HFIR specimens.

Table 4 - "Black Spot" Damage Microstructure

\begin{tabular}{|c|c|c|}
\hline $\begin{array}{c}\text { Irradiation: } \\
\text { Specimen }\end{array}$ & Mean Diameter & $\begin{array}{c}\text { Density } \\
\left(\mathbf{1 0}^{\mathbf{1 7}} / \mathbf{c m}^{\mathbf{3}}\right)\end{array}$ \\
\hline \hline $\begin{array}{c}\text { R-tank: Disk RA3- } \\
\text { 1D, 3D (Type 304 } \\
\text { SS) }\end{array}$ & $1.85 \mathrm{~nm}$ & 2.9 \\
\hline $\begin{array}{c}\text { UBR: 1HA21-1, -2 } \\
\text { (Type 304 SS) }\end{array}$ & $1.66 \mathrm{~nm}$ & 6.0 \\
\hline $\begin{array}{c}\text { UBR: 7W7 (Type } \\
\text { 308 SS, delta } \\
\text { ferrite phase) }\end{array}$ & $5.2 \mathrm{~nm}$ & 0.020 \\
\hline $\begin{array}{c}\text { HFIR 1Q: F50-X1 } \\
\text { (Type 304L SS) }\end{array}$ & $2.7 \mathrm{~nm}$ & 5.5 \\
\hline
\end{tabular}

\section{Effect of Microstructure on Mechanical Response}

The irradiation exposures of the materials in the database were at and above levels of saturation of hardening. Austenitic stainless steels irradiated at low temperatures $\left(<300^{\circ} \mathrm{C}\right)$ show "saturation" of radiation hardening or hardening which is regarded as insensitive to exposure [9]. Prior to saturation, the change in yield strength is linear with (fast fluence) $\approx 1 / 2$ as shown by Higgy and Hammad for Type 304, 316, and 347 stainless steels in a low temperature $\left(<100^{\circ} \mathrm{C}\right)$ irradiation performed in the High Flux Reactor at Petten [10]. Saturation of hardening at a fast fluence of $4 \times 10^{19} \mathrm{n} / \mathrm{cm}^{2}\left(E_{n}>1 \mathrm{MeV}\right)$ was identified [10]. Makin and Minter [11] developed a model describing the functional dependence of the change in the lattice strengthening, $\Delta \sigma_{i}$, with fluence:

$$
\Delta \sigma_{\mathrm{i}}=\mathrm{A}[1-\exp (-\mathrm{B} \Phi)]^{0.5}
$$

where $\mathrm{A}$ and $\mathrm{B}$ are constants.

The expression reduces to $\Delta \sigma_{i} \propto \Phi^{0.5}$ at low fluences and approaches $\mathrm{A}$ at high fluences (saturation). Note that the lattice strengthening is defined in terms of the lower yield point, $\sigma_{\mathrm{y}}$, where:

$$
\sigma_{\mathrm{y}}=\sigma_{\mathrm{i}}+\mathrm{k}_{\mathrm{y}} \mathrm{d}^{-0.5} \text {, where } 2 \mathrm{~d} \text { is the grain diameter and } \mathrm{k}_{\mathrm{y}} \text { is }
$$
a constant.
The second term is the expression for dislocation hardening based on the stress required to operate dislocation sources. Both $\sigma_{i}$ and $\mathrm{k}_{\mathrm{y}}$ increase with fluence [12] although the second term is observed to be a small percentage of $\sigma_{i}$ in irradiated copper and nickel [11] and in the present results of the stainless steel.

The derivation for change in lattice strengthening is based on assumptions that include the existence of a volume around each hardening obstacle (defect cluster) in which no new obstacle could be nucleated with additional irradiation. The model ignores the hardening effects of defect cluster coarsening and the production of additional hardening species (e.g. helium bubbles and transmutation species) which would occur more slowly than the initial production and saturation of number of the clusters in the irradiation and are suggested to account for the trend of increased hardening with fluence dataset.

Models for lattice strengthening, based on Orowon's theory for athermal bowing of dislocations around obstacles on a slip plane, were reviewed by Bement [13]. The expression for the athermal change in lattice strength is typically cited as the change in yield strength and is $[12,13]$ :

$$
\Delta \sigma_{\mathrm{y}}=\operatorname{M\alpha } \mu \mathrm{b}(\mathrm{Nd})^{0.5}
$$

where $M$ is the Taylor factor [12] and $\alpha$ is the barrier strength, $\mu$ is the shear modulus, $b$ is the Burgers vector, and $(\mathrm{Nd})^{0.5}$ is the mean barrier spacing with $\mathrm{N}$ given as the total number of barriers, and $\mathrm{d}$ as the average barrier diameter.

This model is applied to the microstructural results of the analysis of the F50-X1 specimen with the average yield strength $(0.2 \%$ offset $)$ test results at $125^{\circ} \mathrm{C}$ from the $\mathrm{F} 50$ materials in the unirradiated condition and the irradiation condition. The average change in yield strength between the 1Q specimens F50-1, -6, -8, -9, and -12 and the non-irradiated 1Q specimens F50-113, $-101,-86$, and -108 is $36.72 \mathrm{ksi}(253.2$ $\mathrm{MPa}$ ). With the Taylor factor of 3.06 [10], the shear modulus of $58 \times 10^{3} \mathrm{MPa}$, a Burgers vector of $2.544 \times 10^{-10} \mathrm{~m}$, and with a total number density of clusters of $5.5 \times 10^{23} \mathrm{~m}^{-3}$ and an average diameter of $2.7 \times 10^{-9} \mathrm{~m}$ (Table 4), a value of $\alpha=$ 0.146 is obtained. A value of $\alpha$ of 0.2 was obtained by Yoshida [14] in low-temperature-irradiated Type 316 stainless steel for several defect cluster densities with average diameters of $1 \mathrm{~nm}$. This value must be adjusted by using the Taylor factor of 3.06 rather than a Tresca factor of 2; however, to correctly relate the shear strengthening to the yield strengthening in a multigrain material. With this correction, the Yoshida result would be $\alpha=0.131$, in good agreement to the present results.

Two considerations must be noted in deriving barrier strength and estimating the change in yield strength based on the microstructure. First, $\alpha$ should be considered a function of d. Second, the barrier hardening model applied in deriving $\alpha$ does not consider the strong temperature dependence of $\sigma_{i}[11$, 13]. If the non-irradiated change in lattice strengthening with test temperature has the same dependence as the irradiated change, then the change in yield strength would be temperature insensitive. A comparison of the change in yield strengths at 25 and $125^{\circ} \mathrm{C}$ (reference 1) indicates a slightly higher change in 
yield at 25 compared to $125^{\circ} \mathrm{C}$. The base materials irradiated to approximately $10^{21} \mathrm{n} / \mathrm{cm}^{2}$ and tested at $25^{\circ} \mathrm{C}$ show an average change in yield of $57 \mathrm{ksi}$. In comparison, the base materials irradiated to approximately $3 \times 10^{21} \mathrm{n} / \mathrm{cm}^{2}$ and tested at $125^{\circ} \mathrm{C}$ show an average change in yield of $47 \mathrm{ksi}$. Similarly, the F50 materials in the 1Q irradiated to 5 to $9 \times 10^{21} \mathrm{n} / \mathrm{cm}^{2}$ show an average change in yield of $36 \mathrm{ksi}$; the R-tank materials irradiated to $7 \times 10^{20} \mathrm{n} / \mathrm{cm}^{2}$ have a wide range of change with values from 25 to $45 \mathrm{ksi}$ [1]. The test temperature of $25^{\circ} \mathrm{C}$ was used in Yoshida's study [14], whereas the test temperature of $125^{\circ} \mathrm{C}$ was used in this present study in deriving the barrier strength.

\section{IN-SERVICE INSPECTION - REACTOR TANK FLAW ACCEPTANCE CRITERIA}

An ultrasonic in-service inspection program was developed for the SRS primary coolant system. The program was formulated consistent with Section XI of the ASME Boiler and Pressure Vessel Code. An expert working group of S.H. Bush, D.C. Adamonis, J.A. Begley, W.E. Cooper, H.S. Mehta, J.G. Merkle, S. Ranganath, J.C. Tobin, S. Yukawa, and SRS personnel was chartered to develop acceptance criteria to disposition indications from ultrasonic test examination of the reactor tanks. The group prepared the technical basis for the acceptance criteria that included an acceptance standard, reexamination standard, disposition procedure for long shallow indications, crack combination rules, and a procedure for acceptance by analysis. Considered in the technical basis were the following.

- Stress and Structural Evaluation

- Fracture Toughness Properties

- IGSCC Behavior

- UT Examination including Methodology, Detection, \& Sizing

The $\mathrm{J}_{\text {deformation }} \mathrm{R}$ curve from specimen $7 \mathrm{HA5}$, the material with the overall lowest toughness, was selected as the property input for flaw stability analysis. The lower bound data of the HAZ component in the C-L direction was consistent with the understanding of radiation damage including the sensitivity to fluence, and the irradiated microstructure.

The expert group recommended J-T analysis for flaw stability using the following curve fitting to the $\mathrm{J}_{\text {deformation }}-\mathrm{R}$ data to develop the J-T material properties:

$$
\begin{aligned}
& \mathrm{J}=\mathrm{C} \Delta \mathrm{a}^{\mathrm{N}} \text { and } \\
& \mathrm{T}=\left(\mathrm{CN} \Delta \mathrm{a}^{\mathrm{N}-1}\right)\left(\mathrm{E} / \sigma_{\mathrm{f}}{ }^{2}\right) .
\end{aligned}
$$

The expression for $\mathrm{J}$ is the power law formulation of the $\mathrm{J}$ $\mathrm{R}$ curve data with the coefficient parameter, $\mathrm{C}$, and the exponent parameter, $\mathrm{N}$ and $\mathrm{T}$ is the tearing modulus. $\mathrm{E}$ is Young's Modulus and $\sigma_{\mathrm{f}}$ is the flow stress, the average of the yield and tensile strengths.

Figure 2 shows the materials J-T curves for the irradiated archival piping materials irradiated and tested at $125^{\circ} \mathrm{C}$. A cutoff at $J_{\text {deformation }}$ of $110 \mathrm{~kJ} / \mathrm{m}^{2}$ to the $7 \mathrm{HA} 5$ data was applied considering the $0.4 \mathrm{~T}$ planform $\mathrm{CT}$ specimen design and evaluation of the J-R curve behavior. The corresponding crack extension, $\Delta \mathrm{a}$, was approximately $3 \mathrm{~mm}$. Additional details on flaw stability evaluation methodology and irradiated property data are contained in references 15 and 16.

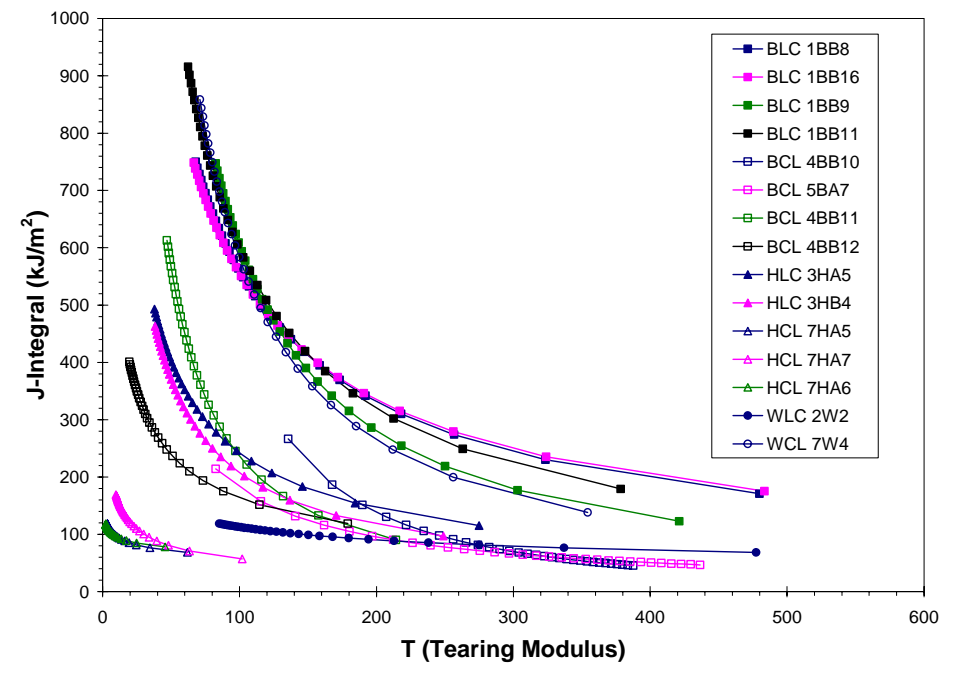

Figure $2-\mathrm{J}_{\text {deformantion }}-\mathrm{T}$ Curves for Base (BLC, BCL), Weld (WLC, WCL), and HAZ (HLC, HCL) Weldment Components of Irradiated Type 304 Stainless Steel

\section{HIGH-LEVEL WASTE TANK MATERIAL PROPERTIES AND APPLICATION TO WASTE TANK ACCEPTANCE BY ANALYSIS}

The Type I and II designs of high level waste storage tanks at the Savannah River Site were fabricated from ASTM A28550T, Grade B firebox quality. Mechanical testing was performed to provide a dataset for tensile and fracture toughness of A285 steel (approximately 100 tests each) from 14 heats of A285 steel including heats that met both Grade B and Grade $\mathrm{C}$ specifications. The heats were selected from commercially available materials. Plates of the semi-killed steel were hot-rolled, consistent with the waste tank materials of construction.

The material and test variables expected to significantly effect the mechanical response were identified, and a statistically-designed test matrix to quantify the strength of the effect and interactions of the variables was constructed. The test matrix variables and the range of conditions are listed in Table 5. The tensile specimen was a standard design and tested to ASTM E8 specifications. Compact tension design to ASTM E1820 specifications with a $20 \%$ total side groove was used to develop J-R curves for the materials. The static and dynamic loading rates (load-line displacement rates) were $1.24 \times 10^{-4}$ $\mathrm{in} / \mathrm{sec}$ and $0.11 \mathrm{in} / \mathrm{sec}$, respectively. An example J-R curve from the testing of A285 plate material is shown in Figure 3 below (reproduced from reference 18) for a specimen with the L-T (high toughness) orientation.

The effect of composition, temperature, plate thickness and loading rate on strength and fracture toughness is briefly discussed. 


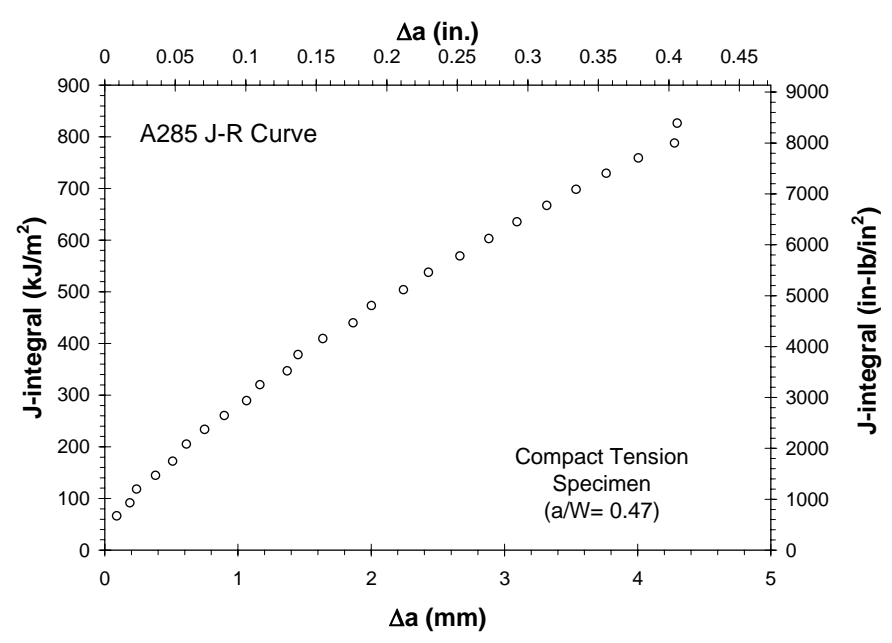

Figure $3-\mathrm{J}_{\text {deformantion }}-\mathrm{R}$ Curve for A285 Plate Base in L-T Orientation

\section{Effect of Composition}

The compositional variables expected to most strongly affect the fracture behavior are carbon content, manganese content, and sulfur content. Carbon strengthens steel primarily by dispersion of pearlite that inhibits plastic deformation. An increase in pearlite has been shown to reduce fracture energy in steels [17]. Manganese strengthens steel by solution strengthening the $\alpha$-iron phase. The test results showed that the most important compositional variable is carbon content with a decrease in fracture energy with carbon. A decrease in manganese was observed to cause a decrease in fracture energy.

\section{Effect of Test Temperature}

The effect of temperature on the fracture energy of steels is well understood [17]. Ferritic steels undergo a transition in fracture behavior as the temperature increases. Fracture energies dramatically increase, and ductile tearing is the predominant mode of failure above the transition temperature. The temperature range and magnitude of the transition have a complex dependence on composition, thermo-mechanical processing, and strain rate.

Previous studies have shown that A285 will be in the upper shelf of fracture energy at the minimum allowed operation temperature of $70^{\circ} \mathrm{F}$. The J-R and tensile results showed little effect of testing at $60^{\circ} \mathrm{F}$ vs. $80^{\circ} \mathrm{F}$.

\section{Effect of Thickness}

In general, an increase in thickness will have triaxial stresses become more predominant, and reduce the fracture toughness. The specimen thickness range in this study, 0.5 to 0.875 inches that span the thickness range of the waste tank sidewalls, was not observed to affect the mechanical response.

\section{Effect of Loading Rate}

The loading rate affects the failure mode of steels with higher loading rate promoting brittle fracture in a material that would otherwise exhibit ductile tearing. If fracture is completely controlled by ductile tearing, higher loading rates will result in higher loads for a given crack extension, and hence a higher fracture energy.
Brittle fracture is not dependent on plasticity mechanisms, and is less sensitive to loading rate. At the conditions in this study, the lower carbon content materials exhibited fracture entirely controlled by ductile tearing at both the static and dynamic loading rates. The higher carbon content materials (at levels outside the specification for the high level waste tank materials) showed evidence of brittle fracture at the dynamic strain rate test conditions.

\section{Application of Fracture Properties to Flaw Acceptance by Analysis \\ Regression analysis to provide fracture toughness} properties at composition-, temperature-, and loading ratespecific conditions has been performed. At present application, the composition of tank plates at flaw locations is uncertain in some cases. For this reason, a high carbon content heat was identified from the testing as a lower bound heat in the lower toughness crack orientation (T-L), and replicate testing was performed.

Table 6 contains the results of the replicate testing and the analysis used to construct the confidence/tolerance intervals for the data. The properties at the $90 \%$ confidence $/ 90 \%$ tolerance interval (90/90) have been applied for flaw disposition in acceptance by analysis in ultrasonic examination of the high level waste tanks in cases where the heat and composition of the tank plate is not available.

For cases in which the heat and composition of tank plate is available, statistical analysis was performed on the data to generate empirical models based upon the data. Eight independent models resulting from combinations of loading rate (static, dynamic), orientation (T-L, L-T) for $\mathrm{J}_{\mathrm{Ic}}$ and $\mathrm{J}_{3 \mathrm{~mm}}$ were developed shown in Table 7. Candidate terms for each model included all terms in the full $2^{\text {nd }}$ order response surface model that contains linear, cross product and squared terms. The statistical significance of terms was determined for each of the models. Those determined to be insignificant were dropped to simplify the expressions. Thickness and grain size were found to be of statistical significance in the models developed for the dynamic strain rate testing data. Compositional variables were found to be of statistical significance for the quasi-static loading rate fracture toughness data.

\section{CONCLUDING REMARKS}

Materials properties that accurately match the degraded service condition are a key input in the demonstration of structural integrity of the structure. An understanding of the degradation mechanism and its effect on the properties further supports informed decisions for application of the properties.

Two case studies using this approach for nuclear systems at the Savannah River Site have been described. Dr. Spencer H. Bush provided leadership to the staff at the Savannah River Site in adopting the framework of the Section XI of the ASME BPVC to inspect the critical structures and disposition indications. Development of structure-specific fracture toughness properties and their application in flaw stability using acceptance by analysis was a key component of the program. 
Table 5 - Test Matrix Variables for A285 Steel Mechanical (Tensile and Fracture Toughness) Testing

\begin{tabular}{|l|l|l|l|l|}
\hline \multicolumn{1}{|c|}{ Variable } & \multicolumn{2}{c|}{ Type } & \multicolumn{1}{c|}{ Midpoint } \\
\hline Temperature & Continuous & $60^{\circ} \mathrm{F}$ & $80^{\circ} \mathrm{F}$ & $70^{\circ} \mathrm{F}$ \\
\hline Carbon Content & Continuous & $0.08 \mathrm{wt} \%$ & $0.29 \mathrm{wt} \%$ & $0.185 \mathrm{wt} \%$ \\
\hline Manganese Content & Continuous & $0.35 \mathrm{wt} \%$ & $0.9 \mathrm{wt} \%$ & $0.625 \mathrm{wt} \%$ \\
\hline Sulfur Content & Continuous & $0.005 \mathrm{wt} \%$ & $0.04 \mathrm{wt} \%$ & $0.0225 \mathrm{wt} \%$ \\
\hline Grain Size & Continuous & 5 & 8 & 6.5 \\
\hline Thickness & Continuous & $0.5 \%$ & $0.875 \%$ & $0.6875^{\prime}$ \\
\hline Loading Rate & Discrete & Static & Dynamic & NA \\
\hline Crack Orientation & Discrete & L-T & T-L & NA \\
\hline
\end{tabular}

Table 6 - Fracture Toughness ( $\mathrm{J}$ at $\Delta \mathrm{a}=3 \mathrm{~mm}$ crack extension) for Lower Bound Heat (E400) in Low Toughness Orientation (T-L). Units are in-lb/in2.

\begin{tabular}{|c|c|c|c|c|c|c|c|}
\hline Sample No. & Technique & Power Law & $\mathbf{J}$ at $\mathbf{3 ~ m m}$ & Mean & $\begin{array}{l}\text { Std } \\
\text { Deviation }\end{array}$ & $\begin{array}{l}\text { One-sided } \\
\text { Tolerance } \\
\% \text { p/Tolerance }\end{array}$ & $\begin{array}{l}\text { One-sided } \\
\text { Minimum } \\
\text { Toughness }\end{array}$ \\
\hline E400T1 & DCPD & $6629.8 \Delta \mathrm{a}^{0.5621}$ & 1911 & \multirow[t]{5}{*}{1875} & \multirow[t]{2}{*}{41} & $90 / 90$ & 1763 \\
\hline E400T2 & DCPD & $8208.3 \Delta \mathrm{a}^{0.6829}$ & 1908 & & & $95 / 90$ & 1736 \\
\hline E400T3 & DCPD & $7014.2 \Delta \mathrm{a}^{0.6203}$ & 1864 & & COV & $90 / 95$ & 1736 \\
\hline E400T4 & UC & $4101.6 \Delta \mathrm{a}^{0.3647}$ & 1881 & & \multirow[t]{2}{*}{$2.2 \%$} & $95 / 95$ & 1704 \\
\hline E400T5 & DCPD & $6532.6 \Delta \mathrm{a}^{0.6004}$ & 1811 & & & & \\
\hline
\end{tabular}

Table 7: Statistical Models for Loading Rate/Orientation Combinations of $\mathrm{J}_{\mathrm{Ic}}\left(\mathrm{in}-\mathrm{lb} / \mathrm{in}^{2}\right)$ and $\mathrm{J}_{3 \mathrm{~mm}}\left(\mathrm{in}-\mathrm{lb} / \mathrm{in}^{2}\right)$

\begin{tabular}{|lll|}
\hline Dynamic, L-T: & $\mathrm{J}_{\mathrm{Ic}}=$ & $47371.1-12604 \mathrm{~T}-672.4 \mathrm{G}$ \\
& $\mathrm{J}_{3 \mathrm{~mm}}=$ & $13424.1-11615.8 \mathrm{~T}$ \\
Dynamic, T-L: & $\mathrm{J}_{\mathrm{Ic}}=$ & No Regression, Normal Distribution with Mean $=2397$, Std. Dev $=1375$ \\
$\mathrm{~J}_{3 \mathrm{~mm}}=$ & $26606.4-441.2 \mathrm{G}$ \\
Quasi-static, L-T: $\log 10\left(\mathrm{~J}_{\mathrm{Ic}}\right)$ & $=$ & $2.156+108.84 \mathrm{~S}+0.082 \mathrm{M} / \mathrm{C}-3342.5 \mathrm{~S}^{2}$ \\
$\log 10\left(\mathrm{~J}_{3 \mathrm{~mm}}\right)$ & $=$ & $3.411+3.577 \mathrm{C}+40.089 \mathrm{~S}-19.295 \mathrm{C}^{2}-1360.8 \mathrm{~S}^{2}$ \\
Quasi-static, T-L:Log $10\left(\mathrm{~J}_{\mathrm{Ic}}\right)$ & $=$ & $9.691-0.528 \mathrm{P}-36.195 \mathrm{C}+0.655 \mathrm{M}-30.956 \mathrm{~S}+2.834 \mathrm{CP}$ \\
$\log 10\left(\mathrm{~J}_{3 \mathrm{~mm}}\right)$ & $=$ & $9.911-12.568 \mathrm{~T}-0.143 \mathrm{G}-1.756 \mathrm{C}+6.584 \mathrm{M}-65.131 \mathrm{~S}+0.2419 \mathrm{GT}$ \\
& & $-5.202 \mathrm{M}^{2}+1368.64 \mathrm{~S}^{2}$ \\
\hline
\end{tabular}

$\begin{array}{lll}\text { Legend: } & \mathrm{C}-\text { Carbon Content (wt\%) } & \mathrm{T}-\text { Thickness (in.) } \\ & \mathrm{M}-\text { Manganese Content }(\mathrm{wt} \%) & \mathrm{G}-\text { Grain Size }(\mu \mathrm{m}) \\ & \mathrm{S}-\text { Sulfur Content }(\mathrm{wt} \%) & \mathrm{P}-\text { Pearlite Fraction } \\ & \mathrm{M} / \mathrm{C}-\text { Manganese/Carbon Ratio } & \end{array}$




\section{ACKNOWLEDGMENTS}

The authors acknowledge the support from the United States Department of Energy (DOE) under Contract No. DEAC09-96SR18500 to the Washington Savannah River Company. S. P. Harris Jr. performed the statistical analysis to develop the empirical equations in support of fracture properties models. F.M. Haggag directed the 12M specimen testing at the Oak Ridge National Laboratory.

\section{REFERENCES}

[1] Sindelar, R.L., Caskey, G.R., Thomas, J.K., Hawthorne, J.R., Hiser, A.L., Lott, R.A., Begley, J.A., and Shogan, R.P., 1993, "Mechanical Properties of 1950's Vintage Type 304 Stainless Steel Weldment Components After Low Temperature Neutron Irradiation," Effect of Radiation on Materials: $16^{\text {th }}$ International Symposium, ASTM STP 1175, Arvind S. Kumar, David S. Gelles, Randy K. Nanstad, and Edward A. Little, Eds., American Society for Testing and Materials, Philadelphia.

[2] Neutron Cross Sections, Volume 2 - Neutron Cross Section Curves, Victoria McLane, Charles L. Dunford, and Philip F. Rose, eds., National Nuclear Data Center, Brookhaven National Laboratory, published by Academic Press, 1988.

[3] Mansur, L.K., Rowcliffe, A.F., Grossbeck, M.L., and Stoller, R.E., 1986, "Isotopic Alloying to Tailor Helium Production Rates in Mixed-Spectrum Reactors," Journal of Nuclear Materials $\underline{139}$ pp. 228236.

[4] Neutron Cross Sections, Volume 1 - Neutron Resonance Parameters and Thermal Cross Sections, Part A, $Z=1-60$, S. F. Mughabghab, M. Divadeenam, and N. E. Holden, eds., National Nuclear Data Center, Brookhaven National Laboratory, published by Academic Press, 1981.

[5] Greenwood, L.R., U. S. Department of Energy Damage Analysis and Fundamental Studies Quarterly Progress Report, August 1983, DOE/ER-0046/14.

[6] Norgett, M.J., Robinson, M.T., and Torrens, I.M., 1975, Nucl. Eng. Des., 33, p. 50.

[7] Hanninen, H., Aho-Mantila, I., and Torronen, K., 1987, "Environment Sensitive Cracking in Pressure Boundary Materials of Light Water Reactors," Int. Journal of Pressure Vessels and Piping, Vol. 30 pp. 253-291.
[8] Zinkle, S.J. and Sindelar, R.L., 1988, "Defect Microstructures in Neutron-Irradiated Copper and Stainless Steel," Journal of Nuclear Materials, 155$\underline{157}$, p. 1196.

[9] Chapter 18 in Fundamental Aspects of Nuclear Reactor Fuel Elements, D. R. Olander, TID-26711-P1, 1976, reprinted by the Technical Information Center, U. S. Department of Energy.

[10]Higgy, H.R., and Hammad, F.H., 1975, "Effect of Fast-Neutron Irradiation on Mechanical Properties of Stainless Steels: AISI 304, 316, and 347," Journal of Nuclear Materials $\underline{55}$, pp. 177-186.

[11] Makin, M.J. and Minter, F.J., (1960), "Irradiation Hardening in Copper and Nickel," Acta Met. 8, pp. 691-699.

[12] Kocks, U.F., 1970, "The Relation Between Polycrystal Deformation and Single-Crystal Deformation," Metallurgical Transactions $\underline{1}$, p. 1121.

[13]Bement, A.L., Jr., 1970, "Fundamental Materials Problems in Nuclear Reactors," in Proc. 2nd International Conf. on Strength of Metals and Alloys (ASM, Metals Park, OH), p. 693.

[14] Yoshida, N., 1990, "Microstructure Formation and Its Role on Yield Strength in AISI 316SS Irradiated by Fission and Fusion Neutrons," Jour. of Nuc. Mat. 174, pp. 220-228.

[15] Metha, H.S., Ranganath, S., Awadalla, N.G., Sindelar, R.L., and Caskey Jr., G.R., 1989, "Fracture Mechanics Evaluation of Savannah River Plant Reactors Considering Irradiated Toughness Properties," in Innovative Approaches to Irradiation Damage and Fracture Analysis, PVP-Vol. 170 American Society of Mechanical Engineers.

[16] Sindelar, R.L., Awadalla, N.G., Baumann, N.P., and Metha, H.S., 1989, "Life Extension Approach to the Reactor Vessel of a Nuclear Production Reactor," in Life Assessment and Life Extension of Power Plant Components, PVP-Vol. 171, American Society of Mechanical Engineers.

[17] Burns, K.W., and Pickering, F.B., 1964, "Deformation and Fracture of Ferrite-Pearlite Structures," Journal of Iron and Steel Institute, pp. 899-906.

[18] Lam, P.-S., Chao, Y. J., Zhu, X.-K., and Sindelar, R. L., 2003, "Determination of Constraint-Modified J-R Curves for Carbon Steel Storage Tanks," ASME Journal of Pressure Vessel Technology, 125, pp. 136143. 